\author{
ALICJA PIHAN-KIJASOWA \\ Instytut Filologii Polskiej \\ Uniwersytet im. Adama Mickiewicza w Poznaniu \\ DOBROSŁAWA GUCIA \\ Poznańskie Towarzystwo Przyjaciół Nauk \\ JOANNA LUBIERSKA \\ Wielkopolskie Towarzystwo Genealogiczne „Gniazdo”
}

\title{
DZIEWIĘTNASTOWIECZNE LISTY GOŃCZE W BADANIACH NAD URZĘDOWĄ POLSZCZYZNĄ WIELKOPOLSKA
}

Polszczyzna wielkopolska z jej odmianami stylowymi, funkcjonalnymi i terytorialnymi najpełniej została opracowana w odniesieniu do stanu dwudziestowiecznego. Dobrze rozpoznane są gwary ludowe regionu, głównie dzięki badaniom Zenona Sobierajskiego i stworzonego przez niego zespołu1. Zaś grupa badaczy skupionych wokół Moniki Gruchmanowej opracowała Stownik gwary miejskiej Poznania (SGMP 1997), zawierający, poza materiałem leksykalnym, także opis systemu fonetycznego i gramatycznego oraz historycznych uwarunkowań specyfiki mowy poznaniaków. Natomiast literacki wariant polszczyzny wielkopolskiej, w ujęciu historycznym, ciągle czeka na swego monografistę. Poza pracami przyczynkarskimi (np. Rzepka 1993; Pihan-Kijasowa 2003) i uwagami w ogólniejszych pracach historycznojęzykowych (np. Bajerowa 1964) znajdziemy niewiele. Dotyczy to także sygnalizowanego w tytule wieku XIX. Dlatego też w kontekście podjętego problemu na szczególną uwagę zasługuje trzytomowa monografia Ireny Bajerowej (1986-2000) Język polski ogólny XIX wieku. Stan i ewolucja. Praca, oparta na bogatym materiale źródłowym i obszernej literaturze przedmiotu, przynosi wielostronny opis polskiego języka ogólnego od ortografii poczynając, przez fonologię z fonetyką, morfonologię, fleksję, składnię (z pominięciem jednak słowotwórstwa i zasobów leksykalnych) zarówno pod kątem przeciętnego stanu języka w tym okresie, dokonującej się normalizacji, jak i widocznych ciągle różnic regionalnych. Autorka stwierdza, że:

już na początku XIX wieku zróżnicowanie regionalne języka polskiego było bardzo małe, zwłaszcza w ramach obszaru dzielnic rdzennych: Wielkopolski, Małopolski i Mazowsza. I dalej w ciągu wieku rozwijają one język dość systematycznie, przy czym Małopolska zawsze (silniej lub słabiej) podtrzymuje swą tradycyjność, wierność starej normie. Warszawa zdradza nieco szybsze tempo rozwojowe [...]. Wielkopolska nie dorównuje Warszawie, ale jest szybsza w rozwoju niż Małopolska (Bajerowa 2000: 162-163).

${ }^{1}$ Ukoronowaniem tych badań jest wielotomowy Atlas języka i kultury ludowej Wielkopolski, red. J. Burszta, Z. Sobierajski, Poznań 1979-2005. 
W swoich rozważaniach o regionalności języka Bajerowa podkreśla też inny typ zróżnicowania między dzielnicami, mianowicie „różnice ilościowe”, które ,polegają na odmienności frekwencji form recesywnych i ekspansywnych, czyli na odmienności tempa rozwoju, a nie na rozbieżności kierunków rozwojowych" (2000: 163). Odnotowuje też, że „Zróżnicowanie jakościowe występuje w rejonach pogranicznych, gdzie pojawiają się, nieliczne zresztą, regionalizmy związane z wpływami obcymi” (2000: 163). I choć w monografii Bajerowej pojawia się problem wpływów obcych, to jednak na uboczu pozostał ważny dla XIX wieku czynnik różnicujący geograficznie ówczesną polszczyznę - zabory i oddziaływanie języka zaborców: $\mathrm{z}$ jednej strony języka rosyjskiego w zaborze rosyjskim, z drugiej - niemieckiego w zaborze pruskim i austriackim. Założyć więc można, że poza dawnymi, tradycyjnymi uwarunkowaniami regionalnymi, dokonał się nowy, nakładający się na stare, terytorialnie uzależnione stosunki językowe, podział na dwie strefy oddziaływań obcych - rosyjską i niemiecką. Przy prowadzonej przez zaborców systematycznej akcji rusyfikacyjnej i germanizacyjnej wpływy tych języków, w mniejszym lub większym stopniu uwidocznione na różnych poziomach języka, szczególnie ujawniły się w odmianie urzędowej (Pihan-Kijasowa, Gucia, 2015). Tymczasem badaniom poddawane są przede wszystkim teksty literackie, mniej podatne (z pominięciem partii stylizowanych) na takie oddziaływania, z natury językowo bardziej tradycyjne. Na potrzebę badań nieartystycznych odmian polszczyzny, zróżnicowanych regionalnie na płaszczyźnie słownictwa, frazeologii, po części składni, zwrócił uwagę Wojciech Ryszard Rzepka, który uznał, że

Było ono [zróżnicowanie regionalne] jednak wynikiem presji języka zaborców, wyrażało się zaś napływem do tych odmian polszczyzny ([...] do języka prasy, języka urzędowego i kancelaryjnego, wojskowego, do terminologii różnych dziedzin nauki, techniki, rzemiosł i zawodów, które się dopiero wówczas rozwijały) mnóstwa germanizmów i rusycyzmów (również kalkowanych frazeologizmów i konstrukcji składniowych) (Rzepka 1997: 15).

Uznając postulat Rzepki za istotny, autorki niniejszego artykułu uwagę skupiły na prasie poznańskiej ukazującej się od końca XVIII wieku do drugiej połowy wieku XIX. Poza kwerendami pozostała prasa kaliska, choć historycznie Kalisz należał do Wielkopolski. Taki wybór źródeł podyktowany został dbałością o spójność językową drukowanych tekstów. Jak wiemy, historyczna Wielkopolska w wyniku drugiego rozbioru Polski (1793 rok) znalazła się pod panowaniem pruskim. Prusy otrzymały wówczas województwo poznańskie, gnieźnieńskie i kaliskie. Stan taki był utrzymany również po trzecim rozbiorze w 1795 roku (Łepkowski, red. 1969: 348-349). Jednak sytuacja terytorialna uległa zmianie w czasie wojen napoleońskich. Na mocy traktatu w Tylży utworzone zostało Księstwo Warszawskie (istniejące w latach 1807-1815), w którego granicach znalazły się ziemie wielkopolskie zabrane przez Prusy w drugim i trzecim rozbiorze. Księstwo Warszawskie formalnie było wolne, ale w rzeczywistości podporządkowane było napoleońskiej Francji, a księciem warszawskim został król saski Fryderyk August I (Łepkowski, red. 1969: 169-170). Dalsze zmiany terytorialne wynikały z postanowień kongresu wiedeńskiego obradującego od września 1814 do czerwca 1815 roku. Kongres został zwołany w celu rewizji zmian terytorialnych i ustrojowych po rewolucji francuskiej i wojnach napoleońskich. Jego decyzje dotyczyły też Wielkopolski, która została podzielona na dwie części: Wielkie Księstwo Poznańskie (obejmujące departament poznański, część bydgoskiego i kaliskiego) - pod panowaniem pruskim oraz Królestwo Polskie, w którego skład weszła gubernia kaliska 
(z Kaliszem i Koninem) - połączone unią realną z Rosją, a po 1832 roku już jako część składowa imperium rosyjskiego (Łepkowski, red. 1969: 151). A więc od 1815 roku znaczna część dawnego województwa kaliskiego, ze stołecznym miastem gubernialnym, znalazła się w strefie oddziaływań języka rosyjskiego. By więc zachować jednolitość językową, należało dokonać zawężenia źródeł do prasy wydawanej w Poznaniu. Poszukując tekstów realizujących urzędową odmianę języka, zwróciłyśmy uwagę na specyficzny typ źródeł na publikowane w prasie listy gończe.

Za cel artykułu postawiłyśmy opis źródła, które może być podstawą szczegółowych badań historycznojęzykowych, ale fakty językowe przywołujemy tylko ilustracyjnie, nie dokonując ich systematycznego opisu. Ponadto warto zaznaczyć, że listy gończe stanowią świetny materiał do badań kilku dyscyplin naukowych: od historii i historii kryminalistyki poczynając, przez etnografię, do historii języka. Prezentowany artykuł ma więc charakter przede wszystkim źródłoznawczy, nie interpretacyjny.

Spośród prasy wydawanej w Poznaniu do ekscerpcji materiałowej wybrałyśmy czasopismo „Gazeta Południowo-Pruska”, wydawane od 1794 do 1806 roku. Było to pismo typowo informacyjne, przedrukowujące głównie artykuły z prasy niemieckiej (Nowakowski 2015). W 1806 roku, po wkroczeniu na ziemie polskie wojsk francuskich, pismo zostało przemianowane na "Gazetę Poznańską" i pod tym tytułem wydawane było do 1815 roku, czyli do czasu utworzenia Wielkiego Księstwa Poznańskiego, a następnie do 1865 ukazywało się jako „Gazeta Wielkiego Księstwa Poznańskiego”4 (Jakóbczyk 1976: 249). „Gazeta" wydawana była początkowo dwa razy w tygodniu - w środę i w sobotę, ale od 1 stycznia 1830 roku już codziennie, oprócz niedziel i świąt. Redaktorem pierwszej edycji („Gazety Południowo-Pruskiej”) był Stanisław Ziołecki. Kolejne tytuły miały kilku redaktorów. W nagłówku „Gazety” figurowali kolejno: Idzi Stefan Raabski (1806-1831), August Wannowski (1831-1845), Jan Rymarkiewicz (1845-1846), Napoleon Kamieński (18461865). Natomiast wydawcą wszystkich trzech tytułów był Wilhelm Decker.

Drugim źródłem, w którym w dużej liczbie publikowane były listy gończe, jest „Publiczny Donosiciel. Dodatek do Dziennika Urzędowego Królewskiey Regencyi w Poznaniu”, czyli „Oeffentlicher Anzeiger. Beilage zu ... des Amtsblatts der Königlichen Regierung zu Posen” jako dodatek do „Amtsblatts der Königlichen Regierung zu Posen” 5 , ukazujący się w latach 1816-1918. „Dziennik” wraz z „Publicznym Donosicielem” ukazywał się równolegle w dwóch językach - po polsku i po niemiecku, przy czym teksty niemieckie stanowiły większość, a w 1876 roku zrezygnowano w ogóle z wersji polskojęzycznej. Wydawcą tego pisma przez wiele lat, podobnie jak wyżej prezentowanych czasopism, był Wilhelm Decker, a druk odbywał się w Drukarni Nadwornej W. Deckera i Spółki.

\footnotetext{
2 Jednocześnie wydawana była jej wersja niemieckojęzyczna „Südpreussische Zeitung”, redagowana przez Jana Samuela Kaulfussa. Jak dowodzi Jerzy Łojek, z dwóch tytułów (,Gazety Południowo-Pruskiej” i „Südpreussische Zeitung”) ,rzeczywistą poczytnością cieszyła się mutacja polska, niemiecka utrzymywana zaś była przy poparciu i z inspiracji władz pruskich. Przez cały okres okupacji pruskiej wydawana w Poznaniu gazeta polska była pracowicie montowaną kompilacją doniesień zagranicznych, przedrukowywanych z prasy obcej, przede wszystkim z gazet niemieckich" (Ło j e k 1976: 65).

3 Wersji niemieckojęzycznej nadano tytuł „Posener Zeitung” (Ł o j e k 1976: 66).

4 Tytuł wersji niemieckojęzycznej brzmiał: „Zeitung des Grossherzogtums Posen” (Ł oj ek 1976: 100).

5 „Dziennik Urzędowy” wydawany był również dla innych części Prus, np. dla Bydgoszczy.
} 
Publikowane w informacyjnej i urzędowej prasie poznańskiej omawianego okresu różne obwieszczenia i zarządzenia pisane były pierwotnie po niemiecku i dopiero wtórnie tłumaczono je na język polski ${ }^{6}$. Dotyczyło to także listów gończych, które drukowane były już w końcu XVIII wieku w „Gazecie Południowo-Pruskiej”. Początkowo listy te nie miały struktury sformalizowanej. W sposób opisowy przedstawiano, jaki czyn został dokonany, kto go dokonał, jak osoba poszukiwana była ubrana oraz proszono o pomoc w jej odnalezieniu. List gończy sporządzony w 1796, opublikowany w 1797 roku, zawierał następujące treści:

List gończy. Dnia 3. miesiąca teraźnieyszego wieczorem, żydowka Jette zamęsczona Hirsch Wolff, w iedyney przytomności matki iey Chaie pozostałey wdowey rzeźnika Jakuba dziecie zrodziła, taż matka toż dzieciątko natychmiast w prześcieradło wziąwszy żywe i w kanał czyli kloak ie wrzuciła. Szczęściem gdy słyszano głos wyiętym zostało. Taż wdowa Chaie Jakubowa po wypełnionym tak okrutnym uczynku zaraz ztąd uszła, i dotąd ieszcze wyszlakowana bydź nie mogła. Ona ma blisko lat 54. tegoż samego wieczora w starym łatanym kamlotownym spodniku, w czerwoney manszestrowey sznorowce z gradytorowemi niebieskiemi rękawami, z starym płociennym w paski fartuchem, i zwyczayną kapką żydowską na głowie odziana będąca uciekła, więcey zaś do domu nie powrociła. Gdy zaś takowy uczynek karę prawną zasłużył, i na poymaniu tey osoby wiele zależy, upraszamy zatym wszelkich wyższych i niższych resp. sądow bardzo uniżenie, w przypadku ta Chaie Jakubowa gdzież kolwiek tylko spotkana bydź miała; aby one natychmiast poymać, i za nadgrodzić się maiących spodziękowaniem unkosztow tu bespiecznie transportować raczyli.

W Poznaniu dnia 6. Decembra 1796. Sąd J.K.Mci Żydowski Pruss-Połud. (GPP, 1797/1).

Budowa listu gończego uległa sformalizowaniu po opracowaniu przez pruskie Królewskie Ministerstwo Policji wytycznych co do zawartości informacyjnej paszportów. Poprzedziło je wprowadzenie w 1790 roku obowiązku posiadania paszportu. Komisja Porządkowa Cywilno-Wojskowa Województwa i Powiatu Poznańskiego tak to thumaczyła:

Gdy wielorakie doświadczenie nauczyło, iak wielkie Kraiowi szkody włóczęgi y Hultaie przynoszą. A Kommissya za cel Urzędowania swego dobro Kraiu ogolne, y wszczególności Każdego Obywatela poczytuie. Więc w myśli zapobieżenia wszelorakim zdroznościom [...] swoie czyni urządzenie y one do publiczney podaie wiadomości.

I. Ustanawia się Blankiety Drukowane na Paszporty pod tytułem: Kommissya Porządkowa, Cywilno-Woyskowa Woiewodztwa y Powiatu Poznańskiego, Pieczęcią teyże Kommissyi znaczone y nummerowane (Kommissya 1790).

Szczegółowe wytyczne co do podawanych w paszporcie informacji opublikowano w dodatku do numeru 42 z 1817 roku „Dziennika Urzędowego”. W dziale $O$ kształcie paszportów czytamy, że paszport musi posiadać każdy obywatel powyżej czternastego roku życia. Podobnie jak współcześnie paszporty miały określony okres ważności i w niektórych przypadkach były wizowane. Opracowano osiem formularzy paszportowych, z czego

${ }^{6}$ Wszystkie rozporządzenia, ogłoszenia, listy gończe podpisywane były albo przez właściwy urząd państwowy, albo przez właściwego urzędnika pruskiej administracji. Wtórnie teksty te były tłumaczone na język polski. Tłumaczy z nazwisk nie znamy. Można jednak założyć, że tłumaczeniem zajmowali się specjalnie do tego zadania zatrudnieni urzędnicy. Mogli to być zarówno Niemcy znający język polski, jak i Polacy zatrudnieni w pruskich urzędach (P i h a - K i j a s ow a, Guc i a, 2015). 
można wnioskować, że i paszportów było kilka rodzajów. Podawano w nich, skąd dany obywatel wyruszał w podróż, kto mu towarzyszył, w jakim celu podróż odbywał, określano trasę podróży z wyszczególnieniem miejsca docelowego oraz termin ważności dokumentu. Ważnym działem niektórych rodzajów paszportu był rysopis jego posiadacza, ułatwiający identyfikację osoby. Paszport wymagający rysopisu sporządzany był według dwudziestu określonych przez urząd punktów. Wymagał podania następujących informacji:

1. imię i nazwisko, 2. stan, 3. ojczyzna, 4. miejsce stałego pobytu, 5. religia, 6. wiek, 7. wzrost podawany w stopach i calach, 8. włosy, 9. czoło, 10. brwi, 11. oczy, 12. nos, 13. usta, 14. zęby, 15. broda, 16. podbródek, 17. twarz, 18. cera, 19. postawa, 20. szczególne znaki.

Od tego czasu budowa listu gończego uległa znacznej formalizacji. Oprócz informacji o typie dokonanego przestępstwa podawano szczegółowy rysopis sprawcy zgodny z przytoczoną wyżej instrukcją (Gucia, Lubierska 2014: 23). Na przykład w „Gazecie Wielkiego Księstwa Poznańskiego” w numerze 287 z 7 grudnia 1832 roku opublikowano:

List gończy. Opisany niżej Józef Skibiński, który u nas jako Exekutor był umieszczony, skręciwszy na bok znaczne summy pieniężne, i innemi jeszcze czynami z zapomnieniem obowiązków połączonemi oszukawszy mieszkańców obwodu sądowego, przeszedł w Kwietniu r. z. do Królestwa Polskiego i przyjął tam wojskową służbę, a tym samym uniknął indagacyi i karze.

Wszystkie tedy władze cywilne i wojskowe upraszamy niniejszem, ażeby Skibińskiego, na którego schwytaniu wiele zależy, i który przed niejakim czasem w jednej wsi pod Ostrowem w bliskości Kalisza spostrzedz się dać miał, w razie natrafienia przyaresztować i do nas przystawić kazały.

Krotoszyn, d. 13. Października 1832. Sąd Xięstwa Thurn i Taxis.

Rysopis.

1) Imie i nazwisko: Józef Jan Skibiński; 2) miejsce urodzenia, Warszawa; 3) teraźniejsze miejsce pobytu, podług domniemania, Królestwo Polskie; 4) religia, katolicka; 5) wiek, 41 lat; 6) wzrost, 5 stóp 6-7 cali; 7) Włosy, ciemno-blond; 8) czoło, płaskie; 9) brwi, blond; 10) oczy, niebieskie; 11) nos, zwyczajny, na końcu płaski; 12) usta, zwyczajne; 13) broda, blond; 14) zęby, dobre; 15) Podbrodek, nieco płaski; 16) twarz, owalna; 17) cera, zdrowa; 18) postać, mierna; 19) mowa, polska; 20) znaki szczególne, niewiadome. - Nadmienia się jednak, że przed kilku laty złamał prawą nogę i dla tego kulawi, lecz prawie nie do pomiarkowania. - Odzież niewiadoma (GWKP 1832/287).

W większości jednak listów gończych bardzo ważną częścią informacyjną jest opis odzieży osoby poszukiwanej. Czasem jest to informacja bardzo lakoniczna, jak np.

\section{Odzież.}

Czarny sukienny frak, takież pantalony, kamizelki niemiał, czarny zwyczajny kapelusz i takież nowe boty (GWKP 1831/131).

Częściej jednak organ wystawiający list gończy, mając więcej informacji, odzież osoby poszukiwanej opisuje bardziej szczegółowo, np. „czeladni kunsztu mularskiego” oskarżony o „kradzież gwałtowną":

ubiór: czapka z sukna zielonego z daszkiem, surdut z sukna czarnego z guzikami obszytemi, kamizelka z sukna granatowego, kaftanik z szycu modrego, chustka gingasowa czerwona z stryf- 
Iiff goricy. Whoczga podeyrzeniu, ze konie kradat, podpadty, Jozef Matewikt lab Kazimierz Jaroszewiki, iak fiz̨ teź nazywa, 1 z Primentu, miedaleko Pozpania, lak powiada rodew itft, maiący 43 lat, wzrottu wysokiego mocnego, twar'zy ctarhiawey, maiacy czarne ocięte w fosy i takowe wąsy, tadziesz kresz nad le wym okieon, nofi ftarą-tozdartą koszule, takowe ikorzane pludry, kamizelkę ol wwowego koloru, nuebitikie pollkie suknie Ina tychźe ciemno zielony nakrapiany polfki surdut z potrzebami czapke oli $k 0$ wego koloru 2 fiwemi barankami i ma plaszcz nq. Wy sukienny niebiciki biald flanela podszyty, whcziga ten, ktory tylko po pollku mowi, miat sposobnoté gatrownie wydobyć fię 2 wiegienia w. przeszley nocy, upraszaiz fię więc wszyflkie tak woylkowe iak o i cy wilne zwierzchności, ieby rego Maiew ikiego alias Jaroszéwflkiego, iezeil fię pokaźe areszto wać i za powrocenienu kosztaw tiszay odethać kazaly. W Kaliszu, dra 4 Styczaia roke 1798 .

List gończy za Józefem Majewskim alias Kazimierzem Jaroszewskim, „Gazeta Południowo-Pruska” 1798, nr 5

niami modremi, spodnie granatowe sukienne, spodnie z żółtego nankinu, bóty długie, pończochy z bawełny i 1 koszulę (D 1838/9: 171-172).

Czy też kobieta pozostająca u szewca w służbie, podejrzana o podpalenie, ubrana była:

czypek kartonowy ${ }^{7}$ pstrokaty z wstążką białą, chustka modrodrukowana na głowie, chustka na szyi bawełniana czerwono pstrokata, kaftanik kartonowy szaropstrokaty, spodnik płócienny modry z rękawami, spodnik wełniany w paski zielone z kaftanikiem płóciennym modrym, fartuch w białe, zielone i czerwone paski, parę pończoch bawełnianych białych, parę trzewików skórzanych (D 1838/21: 382).

Omawiane listy gończe, publikowane w prasie poznańskiej i w „Donosicielu Publicznym” (dodatku do „Dziennika Urzędowego”), są wartościowym, a dotąd nieopisanym źródłem do badań historycznojęzykowych. Przynoszą ciekawy materiał reprezentujący dziewiętnastowieczną urzędową odmianę polszczyzny. Poza cechami językowymi właściwymi dla polszczyzny ogólnej tego czasu (w tym cechami dziś już niejednokrotnie przestarzałymi czy wręcz archaicznymi, jak np. przymiotnikowo-zaimkowe końcówki -em,

7 Wyraz ten w dziewiętnastowiecznych listach gończych występuje w postaciach obocznych: kartonowy, katunowy, kattunowy 'bawełniany'. Jest derywatem do nm. Kattun. 


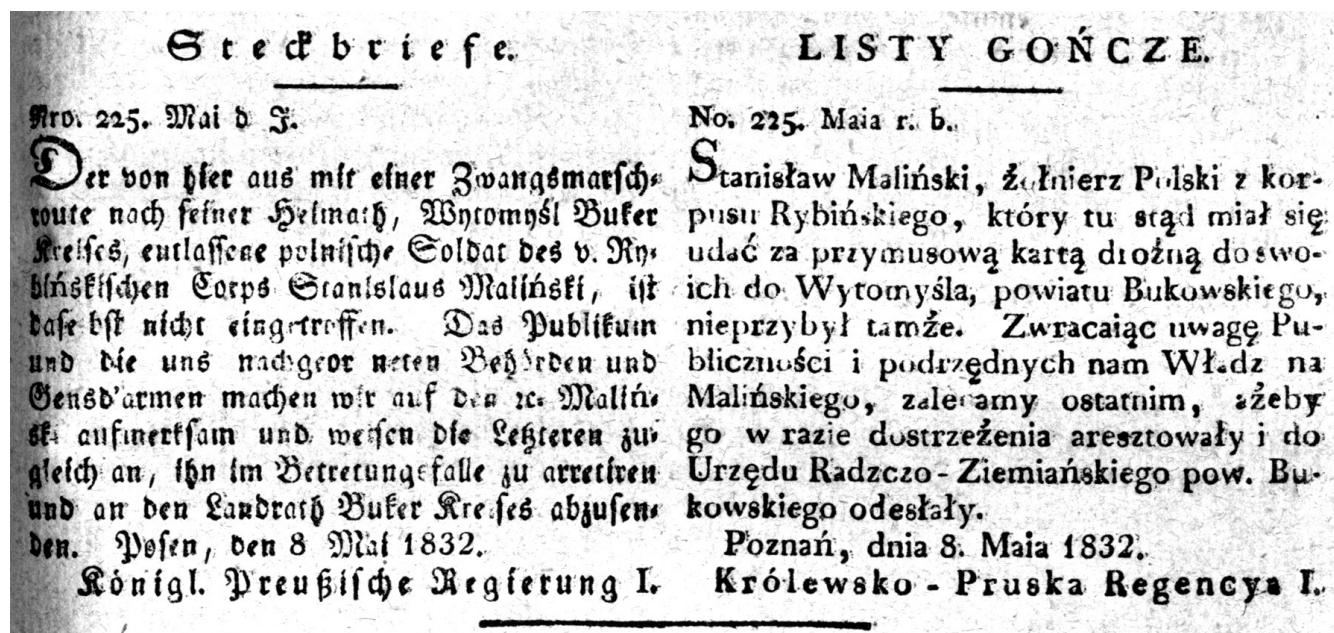

List gończy za Stanisławem Malińskim, „Donosiciel Publiczny” 1832, nr 20

-emi; szerszym zakresem stosowania końcówki dopełniacza 1. mnogiej rzeczowników -ów, obejmującej także rodzaj żeński i nijaki), pojawiają się właściwości językowe charakterystyczne dla wariantu wielkopolskiego i to wynikające zarówno $\mathrm{z}$ dawnych, tradycyjnych uwarunkowań regionalnych, jak i z nowego podziału Polski spowodowanego zaborami.

Wśród regionalizmów rodzimych odnotować trzeba często pojawiające się formacje słowotwórcze z sufiksami przymiotnikowymi -aty, -ity||-yty (występują zawsze jako warianty formacji z sufiksami -asty, -isty||-ysty), jak np.: kończaty (D 1832/1), piegaty (D 1832/35), pleczyty (A 1817), osobity 'osobisty' (A 1817/17). Ten typ derywatów, łączonych z regionem wielkopolskim, znanych także dzisiejszym ludowym gwarom regionu i gwarze miejskiej Poznania, notują liczni badacze (Klemensiewicz 1974: 58; Dejna 1973: 200-201, mapa 44; Gruchmanowa 1997: 35; Gruchmanowa, Witaszek-Samborska, Żak-Święcicka 1986: 18).

Do dziewiętnastowiecznych wielkopolskich form regionalnych z zakresu fonetyki należy przejście wygłosowego $-e j>-i \|-y$. W wiekach wcześniejszych ta cecha językowa miała znacznie szerszy zasięg geograficzny, ale zawsze najliczniej poświadczona była w Wielkopolsce (Ostaszewska 2002:14; Pihan-Kijasowa 1999: 63). Obecna jest także we współczesnej gwarze miejskiej Poznania (Gruchmanowa 1997: 30: Gruchmanowa, Witaszek-Samborska, Żak-Święcicka 1986: 24). W omawianych listach gończych ograniczona jest do kilku męskich imion własnych, w których końcowe - ej przeszło w -y, np.: Andrzy (D 1816/7) czy Błaży (GWKP 1816/31).

W cytowanych listach gończych zdarzają się także regionalizmy leksykalne, jak np. latowy 'letni' (D 1822/30), jako regionalizm kwalifikowany zarówno przez słowniki (SGMP; SGP), jak i opracowania dotyczące gwary miejskiej Poznania (Gruchmanowa, Witaszek-Samborska, Żak-Święcicka 1986).

Natomiast cechami językowymi uwarunkowanymi geograficznie, ale będącymi efektem zaborów, a więc o proweniencji niemieckiej, są zarówno zjawiska z zakresu fonetyki, jak 
np. postać frandzle (D 1832/32), będąca odpowiednikiem nm. Frangen (analogicznie ten typ form interpretują Irena Bajerowa 1986: 105 i Kleszczowa red. 1996: 269-270), jak i często spotykane w listach gończych zjawisko fleksyjne, polegające na nieodmienności nazwisk, jak np.: żydowka Jette zamęsczona Hirsch Wolff (GPP 1797/1). Wydaje się, że tłumacz przejmował formę nazwiska z pierwotnej niemieckiej wersji tekstu, nie dostosowując jej do wymogów polskiej fleksji.

W listach gończych wpływ języka niemieckiego ujawnił się też w budowie zdania, a dotyczy głównie konstrukcji określającej wiek osoby poszukiwanej. Czytamy bowiem: zyd Leyb Irzyk Kotczak z Kalisza rodem, iest swey professyi krawcem, 18. lat stary (GPP 1797/61), Joanna Ludwika Wittych [...] Stara 56 lat (D 1823/21); znaleziono we wsi Czarnym lesie [...] w dole od kartofli zwłoki dziecka ptci niewieściej około 7 miesięcy starego (D 1838/4: 81). Analogiczne konstrukcje składniowe notowane są nadal w gwarze miejskiej Poznania (Gruchmanowa 1997: 24; Gruchmanowa, Witaszek-Samborska, Żak-Święcicka 1986: 28).

Liczne germanizmy pojawiły się także w zasobach leksykalnych, np.: forszpan 'stangret, woźnica' - nm. Virspann (D 1816/4), fronfast || fronfest 'więzienie' - nm. Fronfest (D 1819/26; D 1832/27), mec ‘jednostka miary' - nm. Meßen (D 1832/34), szefel 'miara objętości’ - nm. Scheffel (D 1832/34).

Wskazane typy regionalizmów wielkopolskich, w artykule udokumentowane nielicznymi tylko, arbitralnie dobranymi zjawiskami językowymi, dostatecznie zaświadczają sygnalizowaną we wstępnej części artykułu dwuwarstwowość cech lokalnych: są to bowiem, z jednej strony, tradycyjne regionalizmy od dawna znane w Wielkopolsce, z drugiej zaś warstwa nowych regionalizmów kontaktowych o proweniencji niemieckiej.

Na uwagę zasługuje także słownictwo tematyczne listów gończych, zbudowane wokół ministerialnych wytycznych dotyczących zawartości informacyjnej paszportów i opracowanych na ich podstawie listów gończych. Najliczniejsze pola tematyczne grupują słownictwo z kilku zakresów ${ }^{8}$.

Do ciekawszych należą nazwy zawodów wykonywanych przez osoby dopuszczające się przestępstw, np.: kominiarczyk (D 1836/5), kowalczyk (D 1842/10), krawiec (D 1838/40), leśniczy (D 1832/30), mlynarczyk (D 1832/29), mlynarz (D 1832/27), muzykant (GPP 1797/60), owczarek (D 1842/8), posesor folwarku (GWKP 1816/27), rzé́niczek (D 1832/28), skotarz 'pasterz bydła' (D 1847/40), stużacy (GWKP 1816/80), sukiennik (D 1832/38), szewc (D 1838/21), szlifierz (D 1838/30), tokarczyk (D 1832/34), zygarmistrz (GPP 1797/18);

Pojedynczymi leksemami bądź strukturami wielowyrazowymi określane są dokonane przestępstwa, np.: fatszerstwo (D 1838/7), kradzież (D 1838/7), morderstwo (D 1838/40), oszukaństwo (GWKP 1816/26), podpalenie (D 1838/21), rozbój (D 1838/40), włóczęgostwo (D 1838/7), złodziejstwo (GPP 1797/42), kradzież gwałtowna (D 1838/9), pospolita kradzież (GWKP 1831/131), uszkodzenie człowieka (D 1842/8), zabieranie pieniędzy (GPP 1802/65), narobić znacznych dtugów (GPP 1805/19), przestapienie obowiązu służby (GPP 1802/65), rozmnożenie fatszywych biletów (GPP 1799/18), skręcić na bok znaczne sumy

${ }^{8}$ Przywołując leksemy z poszczególnych pól tematycznych, sprowadzamy je do form podstawowych i podajemy we współczesnej ortografii. 
pieniężne (GWKP 1832/287), zmyślonemi wekslami oszukiwać (GPP 1805/91), dzieciątko [...] żywe w kanat czyli kloak wrzucita (GPP 1797/1);

Bogaty słownik tworzy słownictwo i frazeologia opisujące wygląd człowieka, np.: twarzy chudej, nosa miernego i włosów ciemnych (D 1817/9), średniego wzrostu, czarnych włosów, małych czarnych wąsów, okragłej rydzowatej twarzy, wsklęsłego nosa, cokolwiek ospowaty (GPP 1797/41), włosy czarne kędzierzawe, czoło otwarte, oczy niebieskie, nos proporcjonalny, zarasta czarno, zęby dobre, podbródek okragły, skład twarzy pociagly, cera zdrowa, postać mierna siadta (GWKP 1831/131).

Najliczniejsze jednak pole tematyczne stanowi słownictwo z zakresu odzieży. Są to zarówno nazwy ogólne garderoby, poszczególnych jej gatunków, części odzieży, jej kroju, wzoru i koloru oraz materiałów, z których odzież była wykonana, a także stanu odzieży i dodatków do odzieży, np.: biała westka pikowana (D 1838/29), zielono i czerwono kwiatkowana westka kattunowa (D 1838/36), Biała wetniana duchenka (D 1838/29), granatowy sukienny podarty kabat (D 1842/2), Kamizelka z granatowego sukna (D 1838/27), kamizelka modra sukienna (D 1838/28), kurtka z modrego sukna (D 1838/28), spodnie z szarego nankinu w czerwone paski (D 1838/27), spodnie z sukna sieraczkowego (D 1838/28), spodnie latowe (D 1838/37), czapka kanonierska z rydelkiem (D 1838/27), czapka z brunatnego sukna z rydelkiem świecacym (D 1838/29), granatowa sukienna czapka z barankiem i skórzanym daszkiem (D 1838/29), niebieska sukienna czapka z zastonka skórzana (D 1838/36), czapka niebieskosukienna okragła z manszestrowa obsadka i błyszczacym rydelkiem (D 1838/37), wołoszka z granatowego sukna (D 1838/28), płócienny spodnik w kwiatki niebieskie (D 1842/2), buty o jednym szwie z wysokiemi cholewami (D 1838/29), chustka gingasowa czerwona z stryfniami modremi (D 1838/9)

Tylko ilustracyjnie zaprezentowałyśmy kilka pól tematycznych z przykładowymi reprezentacjami leksykalnymi. Jest wśród nich zarówno słownictwo dobrze znane dziewiętnastowiecznej polszczyźnie ogólnej, jak też rzadkie, a nawet nienotowane przez słowniki języka polskiego. Ponadto obserwuje się wśród cytowanej leksyki tak warstwę wyrazów rodzimych, jak i zapożyczonych.

Zasygnalizowane w artykule problemy ukazują duże możliwości badawcze, jakie stwarzają listy gończe publikowane $\mathrm{w}$ informacyjnej i urzędowej prasie poznańskiej, wydawanej od końca XVIII do drugiej połowy XIX wieku. Prawie każdy numer „Gazety” publikował interesujące nas teksty, a w „Donosicielu Publicznym” takich tekstów w niemalże każdym numerze było po kilka. Otrzymujemy więc niemały zestaw źródeł do oglądu urzędowej odmiany polszczyzny w jej wariancie wielkopolskim z czasów zaboru pruskiego. Udokumentowane w nim zostały zarówno stare, tradycyjne formy regionalne, jak i nowe regionalizmy kontaktowe wynikające $\mathrm{z}$ aktualnych wpływów niemieckich. Te ostatnie tym łatwiej przenikały do badanych tekstów, że były to tłumaczenia z języka niemieckiego. Ale prezentowane teksty to przede wszystkim nieocenione źródło do badań leksykalnych, zwłaszcza kilku wskazanych pól tematycznych licznie zaświadczonych w poddanych oglądowi listach gończych. 


\section{Bibliografia}

Źródła

D: „Publiczny Donosiciel”, 1816-1876, dodatek do: „Dziennik Urzędowy Królewskiej Regencyi w Poznaniu” („Amtsblatt der Königlichen Regierung zu Posen”).

DU: „Dziennik Urzędowy Królewskiej Regencyi w Poznaniu” („Amtsblatt der Königlichen Regierung zu Posen"), 1816-1876.

GPP: „Gazeta Południowo-Prusko”, 1794-1806.

GP: „Gazeta Poznańska”, 1806-1815.

GWKP: „Gazeta Wielkiego Księstwa Poznańskiego”, 1815-1865.

Kommissya Porzadkowa Cywilno-Woyskowa Woiewodztwa y Powiatu Poznańskiego, 1790, Poznań.

\section{Literatura}

SGMP: Gruchmanowa Monika i Walczak Bogdan (red.), 1997, Słownik gwary miejskiej Poznania, wyd. 1, Warszawa - Poznań.

SGP: K a r a ś Mieczysław, R e i cha n Jerzy (red.), 1994, Stownik gwar polskich, t. V, Wrocław Kraków.

B a j e row a Irena, 1964, Kształtowanie się systemu polskiego języka literackiego w XVIII wieku, Wrocław.

B a j e r o w a Irena, 1986-2000, Polski język ogólny XIX wieku. Stan i ewolucja, t. 1, 1986, Ortografia, fonologia z fonetyka, morfonologia; t. 2, 1992, Fleksja; t. 3, 2000, Składnia. Synteza, Katowice.

D e j n a Karol, 1973, Dialekty polskie, Wrocław - Warszawa - Kraków - Gdańsk.

Gruchmanowa Monika, 1997, Opis systemu gramatycznego polszczyzny Poznania, [w:] Gruchmanowa Monika, Walczak Bogdan (red.), Stownik gwary miejskiej Poznania, wyd. 1, Warszawa - Poznań, s. 20-44.

Gru chman ow a Monika, Wit a s ze k-S a mbors ka Małgorzata, Ża k-Ś wi ęc i c k a Małgorzata, 1986, Mowa mieszkańców Poznania, Poznań.

G u c i a Dobrosława, L u bi e r s k a Joanna, 2014, „Jako cię widza, tako cię pisza”. Obraz Wielkopolanina $w$ świetle listów gończych 1. połowy XIX wieku, Poznań.

Jakóbczyk Witold, 1976, Prasa polska $w$ Wielkopolsce $w$ latach 1832-1858, [w:] Ł o j e k Jerzy, (red.), Prasa polska w latach 1661-1864, Warszawa, s. 247-259.

K l e m e n s i e w i c z Zenon, 1974, Historia języka polskiego, Warszawa.

K l e s z c z o w a Krystyna (red.), 1996, Stowotwórstwo języka doby staropolskiej. Przegląd formacji rzeczownikowych, Katowice.

Łe p k ow s k i Tadeusz (red.), 1969, Stownik historii Polski, wyd. 5, Warszawa.

Ł o j e k Jerzy, 1976, Prasa polska w latach 1661-1831, [w:] Łojek Jerzy, (red.), Prasa polska w latach 1661-1864, Warszawa, s. 11-109.

Now a k ow ski Andrzej, 2015, Gazety regionalne do 1919 r. w zbiorach Biblioteki Uniwersyteckiej w Poznaniu, ich stan zachowania $i$ ochrona, [w:] http://lib.amu.edu.pl/konferencja2/ materialy/A.Nowakowski/gazety [dostęp: 10.08.2015].

Ostas zew sk a Danuta (red.), 2002, Polszczyzna XVII wieku. Stan i przeobrażenia, Katowice.

P i h a n-K i j a s o w a Alicja, 1999, Literacka polszczyzna Kresów pótnocno-wschodnich XVII wieku. Fonetyka, Poznań.

P i h a n-K i j a s o w a Alicja, 2003, Literacka polszczyzna wielkopolska XVII wieku a język Samuela ze Skrzypny Twardowskiego, [w:] Mell e r Katarzyna, K ow als k i Jacek (red.), Wielkopolski Maro. Samuel ze Skrzypny Twardowski i jego dzieło w wielkiej i małej Ojczyźnie, Poznań, s. $47-57$. 
Pih a n-Ki j a s ow a Alicja, Gu c i a Dobrosława, 2015, Dziennik Urzędowy Królewskiej Regencyi w Poznaniu z dodatkiem Publiczny Donosiciel jako źródło do badań dziewiętnastowiecznej polszczyzny wielkopolskiej [w druku].

R z e p k a Wojciech Ryszard, 1993, Odrębność regionalna polszczyzny literackiej $w$ Wielkopolsce w XVI-XVII wieku, [w:] B a s aj Mieczysław, Z a gó r s k i Zygmunt, (red.), Munera linguistica Ladislao Kuraszkiewicz dedicata, Wrocław - Warszawa - Kraków, s. 275-282.

R z e p k a Wojciech Ryszard, 1997, Rodowód polszczyzny Wielkopolan, [w:] G r u c h ma now a Monika, Walc zak Bogdan (red.), Stownik gwary miejskiej Poznania, wyd. 1, Warszawa Poznań, s. 7-19.

R z e p k a Wojciech Ryszard, 1993, Status regionalizmów w polszczyźnie XIX w., [w:] Region, regionalizm. Pojęcia i rzeczywistość. Zbiór studiów, Warszawa, s. 133-150.

\title{
ALICJA PIHAN-KIJASOWA, DOBROSŁAWA GUCIA, JOANNA LUBIERSKA
}

\section{$19^{\text {th }}$ century arrest warrants: \\ research into the bureaucratic language in Wielkopolska.}

\begin{abstract}
Summary
Arrest warrants published in the $19^{\text {th }}$ century in Poznan have not been explored as the excellent material they are for historical and linguistic research. Published in the local newspapers and official journals: "Gazeta Południowo-Pruska", "Gazeta Poznańska", "Gazeta Wielkiego Księstwa Poznańskiego" and in "Publiczny Donosiciel. Dodatek do Dziennika Urzędowego Królewskiey Regencyi w Poznaniu", they represent the bureaucratic variety of the $19^{\text {th }}$ century Polish language used in Wielkopolska. On top of the linguistic forms typical of the $19^{\text {th }}$ century, they represent considerable material illustrating two types of regional linguistic formations: old, traditional regionalisms and a layer of new regionalisms resulting from the influence of the German language ${ }^{9}$. What is more, arrest warrants offer interesting lexical material which allows to examine several areas of vocabulary with words related to garment as the best elaborate one.
\end{abstract}

Keywords: $19^{\text {th }}$ century Polish, the bureaucratic variety of the Polish language, regionalism, subject-related vocabulary.

${ }^{9}$ Wielkopolska was part of Prussia between 1795 and 1918 (translator's note). 
